\author{
Vasile Zotic, Diana-Elena Alexandru, Ștefan Dezsi \\ Faculty of Geography, Babeş-Bolyai University, \\ Centre for Research on Settlements and Urbanism, Cluj-Napoca, Romania \\ UDC: $338.482: 316.32 ; 338.48-53: 79$
}

\title{
DEBATE ON TOURISM IN POSTMODERNISM AND BEYOND
}

\begin{abstract}
The nexus between globalization and tourism has been established whereas postmodernism imprints features on the current and future society. Seen as a result of revolutions (technological, behavioural, philosophical, economic) in society and civilizations, postmodernism can be perceived as an adjustment to new conditions involving changes in all fields, ultimately triggering changes in the vision of current civilization, individual's mentality, perception and behaviour, management of resources, adaptation to environmental alterations and, last but not least, converting tourism from an economic activity into a social and leisure lifestyle, from a complementary necessity into a basic need associated with the right of free movement. We therefore addressed forms and types of tourism and their placement on the new trend in accordance with the change in mentality, perception, behaviour, taste, needs and expectations of providers and consumers. Since niche tourism has already been developed by expressing the multiple perspectives of postmodernism, the aim of our paper is to explore the many possibilities to develop niche tourism and prove that
\end{abstract}

\section{Introduction}

The debate on the future of tourism in postmodern times is more current than ever as the existential and socioeconomic paradigms are changing (Jameson, 1983; Van Raaij, 1993; Urry, 1995; Edensor, 2001; Franklin and Crang, 2001; Lee, 2001; Fursich, 2002; Fife, 2004; Arnould and Thom- it is indeed the future of tourism in postmodern times as supple structure particularized on narrow tourist-oriented markets, focusing on the identity, authenticity and uniqueness of place, experiential and active-participative tourism products. Our analysis also results in stating several ground features for the future well-being of niche tourism. Identity and not the extravagance prevails and going back to simple is encouraged. However, if we dare to look beyond postmodernism the concluding remarks highlight the prevalence of inherence than conspicuousness in tourism practice given the continuous movement of population (migration, travelling for work) in contrast with the obvious monopoly of digitalization and technology that transform a large share of consumers from active travellers to passive virtual tourists. Thus we advocate for the emergence of a new tourism, nootourism that would in the end become the bridge to nontourism.

Keywords: postmodern tourism, postmodern tourist, niche tourism, nootourism, nontourism

son, 2005; McGuckin, 2005; Novelli, 2005; Pritchard and Ateljevic, 2011; Rickly-Boyd, 2012; Mak et al, 2012; Tiwsakul and Hackley, 2012; Yeoman, 2012; Hannam et al, 2014; Eugenio-Martina and Campos-Soria, 2014). After the period of economic and social crises, postmodern world is looking for new existential identity and motivation. This new identity gradually configures itself 
by embracing a new set of social values and changes in the economic paradigm. Large consumption market economy already reached its ultimate level of development during modern times whereas postmodernism comes with the demassification of this economy. We witness the early steps of a new economic paradigm - a resource-based economy - which shall focus on sustainable management of the available resources and not on mass production and consumption. As a socioeconomic phenomenon, tourism finds itself in full process of transformation and adaption to the new challenges of postmodernism. With a few steps already taken, from mass tourism to its demassification and then to diversification up to niche tourism, we can conclude that the latter will stand dominant throughout postmodernism. The concept of niche tourism has thoroughly been debated by Marina Novelli (2005) from multiple perspectives, offering a theoretical and practical cases-based rich framework that proves once again the emergence and status of niche tourism, as one of the most sustainable types of tourism in the contemporary world and also during postmodern times, along with particular niches or micro-niches such as: experiential tourism, backpacking tourism, ecotourism, agri-tourism, the everyday tourism and the holiday tourism, dark tourism, medical tourism (Franklin and Crang, 2001; Wight, 2006; Hall, 2011; Daugstad and Kirchengast, 2013). However, having the natural evolution we state that in the end it would represent the transition towards a new tourism, as in nootourism or even non-tourism, as the implicit form of the existence of the society of the future or certifying the end of tourism as a distinctive phenomenon and its inclusion in the everyday life, following Urry's stated conclusion when debating post-Fordist type of consumption (Urry, 1995).

Having the actual state and premises for development of the postmodern society's economy and implicitly tourism it is im- portant to understand the natural development pattern and channel all the forces towards fulfilling this aim. This implies firstly to avoid time and resource loss and find the proper projection of tourism towards niche tourism as the main dominant of the future tourism. Our paper debates on the perspectives of development of postmodern tourism as well as the most suitable prospective tourism niches that can further develop. Thus, our approach individualizes as a retrospection analysis of tourism evolution even from the beginnings as well as a projection correlated with the chronological historical periods. We try to relate to the most recent findings in the field, as well as expound the current traits of tourism and project future and new trends and scenarios of tourism fitted to the next society (see Yeoman, 2012). The main objective of the study is to demonstrate the prospective development of tourism in postmodern times and the most plausible shapes it will take in the nearest future. This approach is absolutely necessary in order to lay the solid and appropriate foundation for the future tourism and not lose time and resources with unsuccessful diverse experiments in this field. This study aims to contextualize tourism in between postmodern period and the beyond of it, the results bringing out traits on both tourism production and consumption and consumer behaviour. Our attempt results in certifying the existence and practice of post-tourism and in proposing some new forms of prospective developing tourism types in the near or farther future. There is a wide field of tourism research, the prevailing subjects focusing on tourism identity, tourism types and forms through definition-based analyses, tourism evolution stages, interrelations of the inner structure elements, providers, intermediaries (Budeanu, 2005), consumers (Tiwsakul and Hackley, 2012), destinations, preferences for particular tourism products. The multiple connotations of tourism reveal new perspectives of approach from defining 
and analysing tourism experience in relation with sleeping during the holiday travel proving that the recovery benefit equalises that of leisure far from home (Valtonen and Veijola, 2011) etc, explaining the necessity of the creative dimension of tourism practice and consumption (Richards, 2011) up to reflections on tourism's philosophical and ontological foundations (Pritchard and Ateljevic, 2011). On the other hand given the evolution of culture-based (mostly urban) tourism, cultural tourists are brought into attention by addressing their relationship with the vocable and the image, when performing the escape into the urban cultural centre aiming to improve and further construct their human self (Manolache and Şerban, 2012). Then again, the extending approaches consist of debated issues of tourism development based on case studies and creating the proper strategy to maintain the competitive advantage of destination (Tzortzaki et al, 2011) or looking for ways of promoting learning tourism in specially designed postmodernist tourism destinations organized in such a way as to feed the need for culture and historical background of the postmodern tourist by re-enactment and active participation of tourists (Fife, 2004).

Framing postmodernism for this tourism-related debate we propose a non-critical but open contextualization of tourism as a process, phenomenon, economic activity or status on a range of different time periods. We do not try to criticize types and forms of tourism that have already developed especially in modern and postmodern times but to emphasize on the possibility of another step forward into the future of tourism and of the globalism, by establishing correlations between the socioeconomic facts and realities and the natural lifecycle of tourism as a phenomenon, arguing for the suitability of change or transformation.

\section{Discussion and findings}

\section{Tourism through time. Pre-modern, modern and post-modern periods}

As old as agriculture or trade, tourism goes further back in time, being one of the first activities practiced or organized by the social individual. Its foundation is tightly related to the historical periods of the humanity, they sharing a strong causative relation (see figure 1). Thus, up to the present time which we still include in postmodernism, tourism has historically been through five distinct stages of development: i) travelling to explore and survive (prehistoric times - 1000 B.C.); ii) early tourism (1000 B.C. - 476 A.D.); iii) pseudo-tourism (476 A.D. - 1789 A.D.); iv) golden tourism (1789 A.D. - 1994 A.D.); v) postmodern tourism (1994 A.D. - 2030 A.D.). Each of these historical periods consists of distinctive phases whose characteristics derive from the traits of touristic activities practiced.

Therefore, the period of travelling for survival and exploration of the surroundings during prehistoric times used to be performed to fulfil the basic needs through several main activities such as: hunting, fruit and seed peeking, operations for finding water resources, tools and other construction materials. This type of travelling cannot be defined as touristic yet, people only being determined by curiosity to find the new beyond their households and local community, thus coming into contact with other human communities, exchanging goods and experiences.

The early tourism age (1000 B.C. - 476 A.D.) has its beginnings in the early ancient ages even though is still tightly connected to the previous features. People become attracted by exceptional elements, natural and social events in the neighbourhoods. The first civilization cores appear which proves favourable to the tourist movement. Also, tourist motivation appears as a direct cause 
for travelling towards these civilization cores, their edifices and institutions. Tourism demand focuses on man-made attractions, such as: imposing buildings, religious, cultural or sports events. The first tourist facilities for cure (thermal baths) and infrastructures are established, such as: inns, public guesthouses.

The pseudo-tourism age (476 A.D. - 1789 A.D.) comprises two distinctive periods:

a) The period of tourism great recession (476 A.D. - 1054 A.D.). As a result of the fall of the great ancient civilizations and their transformation into numerous medieval feudal states, bringing out certain financial challenges, tourist activities are affected by stagnation and ultimately go into destructuring. This is when all previously developed preoccupations for travelling and tourist infrastructures disappear. Europe goes through an ample process of reestablishment of populations and religions. The former religious and cultural edifices are either destroyed or abandoned; travelling becomes increasingly dangerous, therefore tourist activities diminish.

b) The period of Christian pilgrimage (1054 d. Ch. $-1453 \mathrm{~d}$. Ch.) is mostly marked by religious fanaticism when religious wars and pilgrimage towards religious sites intensify. These movements are laying the ground for the next period of tourism and trade development. New road networks and new tourist facilities are established. The first universities are established in Europe, thus encouraging the development of a new cultural tourism. However, due to the frequent conflicts, epidemics and starvation periods, tourism is affected by high spatial and time discontinuity.

Overall, this age is distinguished through an extended regression of tourism and also an ample destruction of infrastructure built during ancient times. Travelling changes its purpose into invasion, forced occupation of territories through conflicts (i.e. the crusades) and loses almost entirely the purpose of exploration, rest, leisure or cure.
The golden tourism age (1789 A.D. - 1994 A.D.) consists of three distinctive stages:

a) The early tourism development (1453 A.D. -1789 A.D.) that coincides with the age of great geographic discoveries, colonial expansion and European cultural development, while culture and science are no longer contaminated by the religious mysticism. Travelling increases along with migration or other types of movements. New trade sea routes are discovered and the number of tourist facilities increases. Thermal and mineral waters become again subject of development and exploitation. The new trade centres become hot spots for tourism development.

b) Individualization of tourism (1789 A.D. - 1914 A.D.) that overlaps the industrial revolution, whereas the first signs of mass tourism appear. Population increases, people change their lifestyle; it is a great period of scientific and technical discoveries, all improving the quality of life and development of tourist activities. Transportation, accommodation and the first economic tourism-related facilities appear, increase and develop (i.e. hotels, complex thermal resorts). For the first time, the journey is organized by economic agents, previously planned and later purchased as a commodity. This sets the foundation of travel agencies and the first steps of international tourism. At the same time, leisure activities are promoted by specialized tourism clubs, such as alpine tourism clubs and holiday associations. Therefore, from individual or small group tourist activities, we now witness the development of mass tourism, organized as holiday journeys or week-end journeys. Culturally, romanticism and impressionism dominate fact that guides tourism demand towards nature and landscape resources, which become dominant. In the second half of the $19^{\text {th }}$ century complex tourist resorts are established leading to the elaboration of the first travel guides and the first tourist mountain itineraries. 
Figure 1: Tourism through time

\begin{tabular}{|c|c|c|c|}
\hline \multirow{3}{*}{$\begin{array}{l}\text { Travelling to } \\
\text { explore/discover the } \\
\text { surroundings to fulfil the } \\
\text { existential (basic) needs }\end{array}$} & \multirow{3}{*}{ 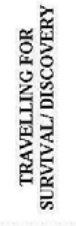 } & $\begin{array}{l}\text { The Stone Age } \\
\text { Discovering fire, incipient stage agriculture, domesticating cattle, first stable settlements, first writing } \\
6000 \text { B. C. }\end{array}$ & 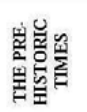 \\
\hline & & $\begin{array}{l}\text { The Bronze Age. First civilizations (Sumerian. Babylonian. Egyptian. Trojan) } \\
3500 \text { B. C. }\end{array}$ & \multirow{6}{*}{ 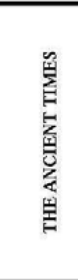 } \\
\hline & & $\begin{array}{l}\text { The Iron Age. Iron tools. Rediscovering writing, agriculture development, domesticating horse, wheel } \\
\text { discovery } \\
1000 \text { B. C. }\end{array}$ & \\
\hline \multirow{4}{*}{$\begin{array}{l}\text { Emergence of the first } \\
\text { civilization cores. } \\
\text { Setting up the first tourism } \\
\text { facilities for cure and } \\
\text { accommodation } \\
\text { infrastructure. }\end{array}$} & \multirow{4}{*}{ 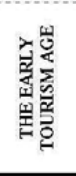 } & $\begin{array}{l}\text { The Classical Greece Period } \\
500 \text { B. C. }\end{array}$ & \\
\hline & & $\begin{array}{l}\text { The Classical Roman Period } \\
\text { IA. D. Jesus Christ is born }\end{array}$ & \\
\hline & & $\begin{array}{l}\text { The Early Christianity Period } \\
313 \text { A. D. acknowledging Christianity in the roman empire }\end{array}$ & \\
\hline & & $\begin{array}{l}\text { The Early Byzantine Period } \\
476 \text { A. D. the fall of the roman empire }\end{array}$ & \\
\hline \multirow{2}{*}{$\begin{array}{l}\text { The age of great recession } \\
\text { Tourism destructuring }\end{array}$} & \multirow{6}{*}{ 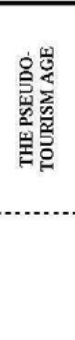 } & $\begin{array}{l}\text { The Migration Period (the period of barbarian invasions). The fall of Greek and Roman order. Preservation } \\
\text { of order in religious Benedictine and orthodox structures } \\
805 \mathrm{~A} \text {. D. the creation of Carolingism empire }\end{array}$ & \multirow{6}{*}{ 萦 } \\
\hline & & $\begin{array}{l}\text { The Byzantine Period. Byzantine supremacy. The break between east and west, between orthodoxy and } \\
\text { Catholicism. Last ethnic restructuring in Europe } \\
\text { 1054 A.D. The Great Schism of the Orthodox Church }\end{array}$ & \\
\hline $\begin{array}{l}\text { The age of Christian } \\
\text { pllgrimage }\end{array}$ & & $\begin{array}{l}\text { The Crusader Period. Cavalry. The supremacy of the crusaders and the contact between civilizations } \\
1270 \text { A. D. The last crusade }\end{array}$ & \\
\hline $\begin{array}{l}\text { Religion-based travelling } \\
\text { and cultural tourism. }\end{array}$ & & $\begin{array}{l}\text { The Growth of the Ottoman Empire. The fall of the Byzantine Empire. The ottoman expansion } \\
1453 \text { A. D. The fall of the Constantinople }\end{array}$ & \\
\hline $\begin{array}{l}\text { The early tourism } \\
\text { development. }\end{array}$ & & $\begin{array}{l}\text { The Age of Discovery (the age of exploration). Discovery of America (Columbus, 1492). Expedition of } \\
\text { Vasco da Gama and the new way/road/path to India (1498). Magellan's expedition around the world (1519) } \\
\text { 1521 A.D. Magellan's expedition around the world }\end{array}$ & \\
\hline $\begin{array}{l}\text { Boost in movement of } \\
\text { population and goods. }\end{array}$ & & $\begin{array}{l}\text { The Renaissance. The colonization of America, the Italian Enlightenment, the protestant reform, Spain, } \\
\text { Portugal. England and France expand colonies, the USA Declaration of Independence } \\
1789 \text { A. D. The French revolution }\end{array}$ & \\
\hline \multirow{3}{*}{$\begin{array}{l}\text { Individualization of tourism } \\
\text { Emergence of tourist resorts } \\
\text { and tourism-related } \\
\text { facilities, travel guides. } \\
\text { The beginning of mass } \\
\text { tourism. }\end{array}$} & \multirow{7}{*}{ 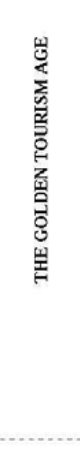 } & $\begin{array}{l}\text { The Age of European Revolution. The French Revolution, The Neapolitan Wars, The congress in Wien, } \\
\text { restoring the absolutist regimes, the early movements of national emancipation } \\
1848 \text { A. D. The revolutionary Europe }\end{array}$ & \multirow{3}{*}{ 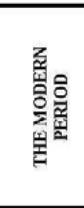 } \\
\hline & & $\begin{array}{l}\text { The Industrial Revolution. Great discoveries in technology and science. The beginning of industrial mass } \\
\text { production } \\
1869 \text { A. D. The universal exhibition in Paris }\end{array}$ & \\
\hline & & $\begin{array}{l}\text { The Age of Imperialism. The expansion of colonial empires, increase of industrial revolution, increasing need } \\
\text { for resources and new markets, the rise of nationalism } \\
1914-1918 \text { A. D. The First World War }\end{array}$ & \\
\hline \multirow{4}{*}{$\begin{array}{c}\text { The age of mass tourism } \\
\text { Travelling as social status } \\
\text { marker. } \\
\text { Increasing need for rest and } \\
\text { leisure. } \\
\text { High diversification of } \\
\text { products services. }\end{array}$} & & $\begin{array}{l}\text { The Interwar Years (period). The fall of the colonial system. New European states. The Great economic } \\
\text { crisis. Expansion of communism and fascism } \\
1939-1945 \mathrm{~A} \text {. D. The second World War }\end{array}$ & ב \\
\hline & & $\begin{array}{l}\text { The Post-war Period. Reconstruction of Europe. Founding UNO. Expansion of communism and fascism } \\
\text { across East and central Europe } \\
1953 \text { A. D. the beginning of the cold war }\end{array}$ & 잉을 \\
\hline & & $\begin{array}{l}\text { The Cold War Period. Found ing NATO, Correa and Vietnam war, the crisis of rockets in Cuba, founding of } \\
\text { EU, the energetic crisis of the ' } 70 \text { s. Afghanistan war. } \\
1989 \text { A. D. the fall of the communism }\end{array}$ & $\sum_{0}$ \\
\hline & & $\begin{array}{l}\text { The Unipolar Era. The global economic and geo-political hegemony of the USA } \\
2001 \text { A. D. world trade centre attacks }\end{array}$ & 롭 \\
\hline Demassiffcation of mass & \multirow{3}{*}{ 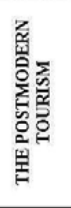 } & $\begin{array}{l}\text { The Multipolar Period. The expansion of international terrorism. Levelling geopolitical and economic power } \\
\text { poles. The crisis of oil } \\
2008 \text { A. D. }\end{array}$ & Z্র \\
\hline $\begin{array}{l}\text { lourism } \\
\text { The age of niche tourism. } \\
\text { Search for authenticity. }\end{array}$ & & $\begin{array}{l}\text { The Global Recession. Worldwide economic, social and geo-political crises, the environmental crisis. The } \\
\text { world on the verge of changing the existential paradigm } \\
2014 \text { A. D. }\end{array}$ & 봅을을 좁 \\
\hline & & $\begin{array}{l}\text { The Age of the Existential Paradigm - the new existential paradigm. Globalization of economy, ample } \\
\text { social movements, transfer to knowledge-based economy } \\
2030 \text { A. D. }\end{array}$ & $\grave{8}^{2}$ \\
\hline \multirow{2}{*}{$\begin{array}{l}\text { Changing economic } \\
\text { paradigm. } \\
\text { Knowledge and leaming } \\
\text { travelling } \\
\text { Virtual tourism and the } \\
\text { armchair tourist. }\end{array}$} & \multirow{2}{*}{ 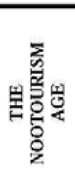 } & $\begin{array}{l}\text { The Age of New Global Enlightenment (the new age of reason). New scientific and technological } \\
\text { discoveries. Transition to resource-based economy } \\
2050 \text { A. D. }\end{array}$ & \multirow{2}{*}{ 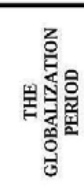 } \\
\hline & & $\begin{array}{l}\text { The Resour ce Based Economy. Change of economic paradigm. Transfer from market economy to resource- } \\
\text { based economy. Early transition to a new planetary civilization } \\
2100 \text { A. D. }\end{array}$ & \\
\hline $\begin{array}{l}\text { Universality of travelling - } \\
\text { lifestyle of the individual. } \\
\text { Transfer from Veblen's } \\
\text { conspicuous to intrinsic } \\
\text { tourism consumption one. } \\
\text { The end of tourism. }\end{array}$ & 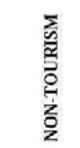 & $\begin{array}{l}\text { Extension of Resource-Based Economy. Post-globalization knowledge-based society. Either the beginning of } \\
\text { a new civilization or human extinction. }\end{array}$ & 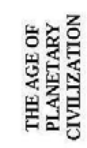 \\
\hline
\end{tabular}


c) The period of mass tourism (1918 A.D. - 1994 A.D.) appears as a natural consequence of a set of triggering factors such as: shortening of working day and week along with industrialization and agriculture mechanization; improved quality of life and the possibility of designating a significant fund for leisure expenses; development and diversification of transportation means and routes and increased travelling speed; diversification of tourist offer covering all range of demand; increased need for recreation and recovery after daily intensive stress; high diversification of tourist facilities and services. Therefore, a large number of people are actively involved in the tourism circuit, by increasing the length of stay and of travel distance. Thus the consumption level increases both for tourism and non-tourism products, tourism becoming one of the basic economic branches in many states. New forms and types of tourism appear as well. By attracting low-income population tourism becomes now a social phenomenon. Since it interconnects with other economic branches it leads to the foundation of large international tourist companies and hotel chains.

Holiday is extended to a greater length, tourists travelling to diverse places and benefitting from services within international tourist networks. Travel agencies develop continuously and large company giants emerge on the tourism market. Overall, this is the ultimate tourism development stage.

Postmodern tourism age (1994 A.D. - 2030 A.D) identifies with two distinctive periods:

a) Demassification of mass tourism (1994 A.D. -2008 A.D.) that occurs once with the demassification of economic production. It consists in an increasing level of specialization of tourist services and the selection of tourism demand; tourism offer inclines toward niche tourism in case of small and particular groups of consumers. The offer is thus particularized based on emotional need and not on material aspects. b) Emergence of niche tourism (2008 A.D. - 2030 A.D.). Niche tourism appears as the alternative to mass tourism, as a more sustainable form of economic activity from the perspectives of product quality offered to consumers and consumed resources. It is certified by the quality of tourists and of the tourism products complying with sustainable development and sustainable tourism practice. This type of tourism is tailored by the consumer and by the locations or activities involved. Therefore it addresses to a small however constant share of consumer market. Its main feature is the uniqueness, the dynamism and highly adaption to the tourism demand. It ultimately represents the future trend of national and international tourism development. Overall, this period can be defined as a transition period towards as now paradigm of tourism development, which we would call nootourism. This transition is operated by the demassification of mass tourism and then regrouping tourist activities in a wide range of tourism niches.

The nooturism age (2030 A.D. - 2100 A.D.) shall represent the new shape that tourism will undertake in the future. In this period tourism will distinguish itself as a practical way of life, therefore changing its status from an economic branch to a daily common activity. Changing the economic paradigm, going from a monetary economy to a resource-based sustainable economy will provide the opportunity to change the existential paradigm, people spending most of their time travelling, aiming to explore and know the world. Thus, tourism becomes the threshold towards the planetary civilization.

Tourism as non-tourism. After 2100 we foresee the transformation of tourism in global tourism as an adaptation to the global resource-based economy. This time, travelling becomes universal and dominant feature of the individuals, somehow the former tourism pattern coming to an end. All political, economic and linguistic barri- 
ers will be overcome due to technology and knowledge, which stand as the foremost aim of the human civilization. The universality of travelling becomes the lifestyle of the new individual in an era during which poverty is hoped to be eradicated and shortages of any kind will be substituted by a natural resource-based economy. Social equality of chances shall be supported by the equality of access to the world's natural resources and their equitable sustainable management in favour of the entire humanity and not only in favour of privileged nations.

\section{Challenges of postmodernism}

\section{Niche tourism - the answer to mass tourism}

Niche tourism stands out as a relatively new form of tourism, developed as a counterpoint to mass tourism in the contemporary world (Novelli, 2005). Mass tourism was designed in accordance with the patters of market economy focusing on large production for large masses of people specific to the Fordist economic period. Massification of tourism provided tourists only a relocation without focusing on the novelty, uniqueness and ambiance that would disconnect them from the daily routine. The direct effect of mass tourism was intense exploitation and accelerated exhaustion of natural and man-made tourism resources, as well as standardization of tourist facilities and services offered. Mass tourism went through the same economic convulsions as other economic branches subsequently affected by restructuration, its ultimate effect being the demassification and hence the individualization of tourism niches.

Both as a reaction and a new and opposite pattern against mass tourism, the concept of niche tourism first stood out through an increasingly diverse set of practices and sophisticated, cosmopolite and sometime aristocratic ways in which niche tourism consumers aimed to stand out, differentiate themselves against the common tourism consumers, thus imposing a rather selective distinction between them and the others (Novelli, 2005). Niche tourism is marked by multiple and large range of variations, not necessarily being framed by rules or strict standards of definition, each of the niches being preferred or accessed by a particular group of tourists, subsequently forming a particular niche market.

The main feature of niche tourism is the strong and complex interrelation between tourism offer and demand at micro-scale. Therefore, niche tourism offer addressed a relatively small number of consumers, precisely delineated and animated by common needs fulfilled by a particular offer. The size of the individualized niche market can highly vary, in the end aiming to be enough large to allow growth and development but enough narrow not be ignored by the competition, basically to find its balance. However, since some of the partisans of this category of tourists are willing to spent significant amounts of money in order to practice and satisfy diverse hobbies, niche tourism can be most often nominated as an elitist form of tourism, distinctively distinguished by the mass tourism, which is dominated by average price tourism products accessible to large number of people. And, the reverse conclusion that a series of niche tourism forms are rather boring may come from some of the tourists who are not so much interested in that kind of hobbies.

Both offer and demand adapt and consider one another according to the characteristics of tourism resource and focus on its sustainable management. The specific offer needs to provide a set of services much more adapted and particularized, able to control all activities and practices operated and also allow the continuous monitoring of signals of the market. The ground features of niche 
tourism include several particulars: 1) continuous search for new, novelty, uniqueness and authenticity and include it in the tourism offer; 2) accentuating the importance of local development, therefore transferring economic development from macro-scale to micro-scale; 3 ) discovering and giving value to new tourism resources, especially geo-, eco- and bio- tourism resources and forms; 4) discovering the new market of consumers with well distinguished preferences; 5) active participation of tourists; 6) sustainable management of resources and decreased negative impact on environment; 7) sense of familiarity at the destination determining relationships between guests and host communities; 8) larger range of products and more complex, flexible and adaptable offer to meet the exigencies, needs and possibilities of prospective consumers; 9) sustainable and more attractive for even more diverse categories of emerging tourists due to its diverse offer.

Having these ground features niche tourism could farther grow and diversify up to a large range of types and subtypes. Thus, we propose an extended version of the conceptual design Novelli (2005) has proposed leaving an open end to the variations niche tourism can evolve to (see figure 2). This development process is only at the beginning, while the perspectives of diversification are even currently visible, fact proven by certain niches, such as medical tourism (see figure $3)$.

At the same time, we emphasize on the increasing presence of disability tourism that first emerged like a supplementary touristic service tourism providers offered in case of demand from a specific group of consumers, not being especially designed to be ranked as niche tourism. Implying particular conditions to be practiced it could very well be considered a micro-niche or even a niche, whose identity will not be based on the particularity of destination or products offered but on the particularity of the consumer itself, and the type of disability only conditioning the type of tourism practiced (cultural tourism, ecotourism or others).

Figure 2. Basic typology of niche tourism

(Novelli, 2005, with modifications)

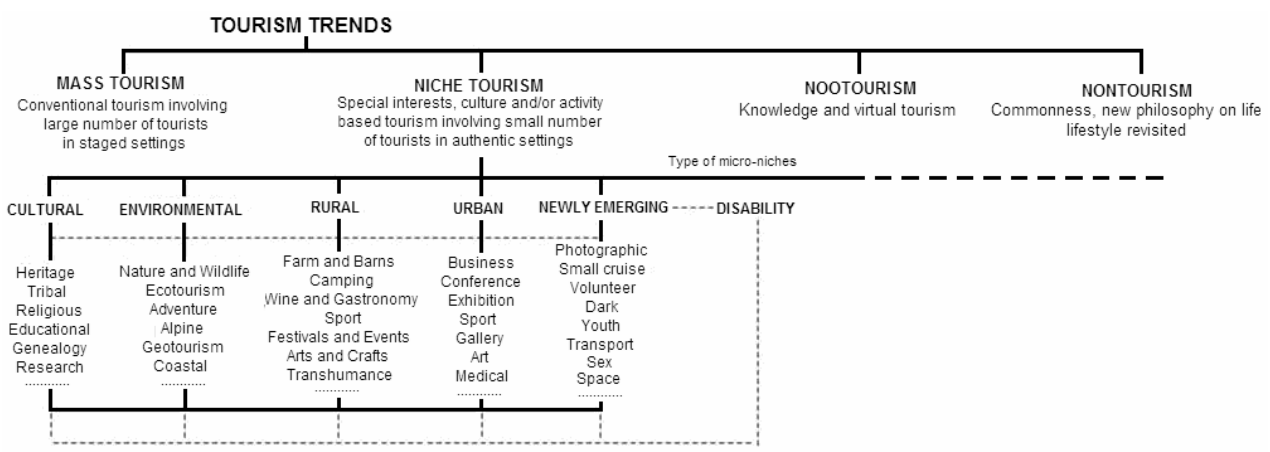


Figure 3. Diversification of medical niche tourism (Hall, 2011)

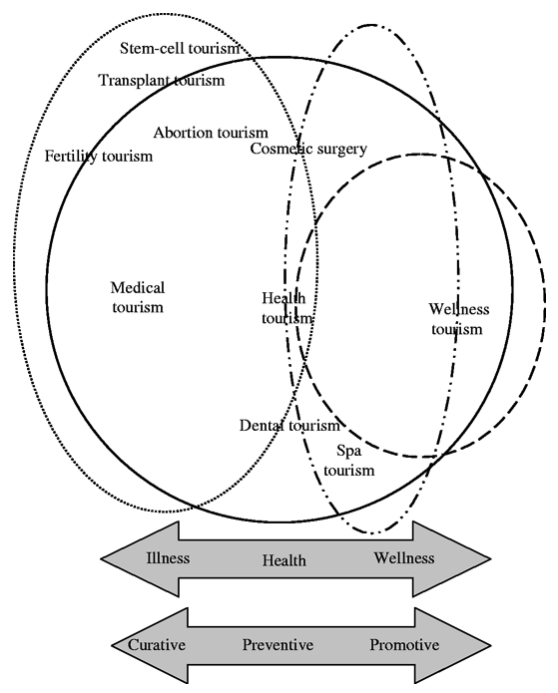

On the other hand, once with the growth of demand for the particular and diversification of the niches, niche tourism can register an apparently paradoxical evolution towards a particular type of destructured mass tourism, which we can generically name mass niche tourism. In the end niche tourism will navigate from micro-scale (microniches) back to macro-scale (macro-niches, i.e. oenological tourism, food tourism, etc.) (Novelli, 2005).

We can conclude the future extended development of niche tourism can be underpinned by the following: know-how in the field in terms of management and future development projection; understanding the concept of niche tourism; existence of professionals that would support tourist activities and operate niche tourism products, who on their turn become the reason for travelling or for choosing that product; particularization of niche tourism offer against other similar niche products; adaption of tourist services and products to the specifics of niche; preservation of niche features in order to sustainably develop it; attrac- tive promotion of touristic niches by using mainly the virtual environment, which will become in fact an important future environment for tourism development and will generate a new tourism form, as in virtual tourism; previous informing and preparation of tourists for their inclusion in a tour; preserve the niche authenticity and limit its pollution with elements of modernism and postmodernism, where the case; eliminate the formalism and use familiar communication according to the tourism specific niche; apply retention policy by including surprise elements in the products offered and reward tourists with various products at the end of their tour; attract and maintain tourism demand by offering products at prices and services adapted to the financial possibilities of the consumers; increase the flexibility and particularity of tourism offer in accordance with the demand and preference of the consumers.

\section{Postmodern tourism and postmodern tourists}

Tourism as economic activity holds an important place in the economy of any territory, through the large scale mobility of people, goods, objects, capital and information across the world (Hannam et al, 2014) the revenues being considerable no matter the type of tourism practiced. The demassification of mass tourism has been contextualized by the global socioeconomic evolution including the global economic crisis as in 2009 the world economy faced the deepest economic crisis of the last decades (the World Bank) therefore affecting tourism demand (Eugenio-Martina and Campos-Soria, 2014).

As the manifestations of postmodernism emerge as specific reactions against the established forms of high modernism (Jameson, 1983) or like an increasing pluralism of styles and genres (Van Raaij, 1993) postmodern tourism takes the shape of a tran- 
sitional pattern evolving from the classical mass production and consumption to tourist-oriented particularized tourism market. Considering postmodern times a framework of brands, a time of variety, abundance and diverse uniqueness, individuals behave and choose tourism and tourism-related products mostly driven by their personality, cultural background, meaning of the objects achieved (tourism destination, souvenirs) and find the post-consumption satisfaction according to the symbolic meaning of the brand purchased and experienced (Yuksel at al, 2013).

Making the distinction between the identity of tourism as an economic activity and the activity of tourists, we consider appropriate to focus our attention on both tourism practice and tourism consumers. Identity of tourism is three-fold as desire, need or common sense in the contemporary society. The multiple connotations of postmodern tourism still comprise all three of them while only the perception of the consumer has changed. Contemporary and post-contemporary tourism and postmodern consumer distinguish through a set of features given by the context. Therefore, postmodern tourists engage in different and diverse tourism practices given their particular preferences shaped by their socioeconomic characteristics, such as age, gender, occupation or education (Eugenio-Martina and CamposSoria, 2014). Or as McGuckin (2005) has stated, they manifest an obvious preference for culture, and subsequently urban culture, becoming engaged in cultural consumption or in brand consumption (Ekinci et al, 2013). Looking for one's self, looking for the real things, for the authenticity offered by that special, unknown place or host, for the uniqueness of spent time or attraction or environment become primary motivations for the postmodern traveller, the postmodern tourist and the consumer market focus on self-directed travel, special interest tourism products (SIT) and the development of spe- cialised niche tourism products (Ali-Knight, 2011). At the same time, the growth of interest in city cultures and urban lifestyles proves the enhancement of cultural consumption (Featherstone, 2007). Despite the explicit preference for immediate destinations and shorter leisure time due to the decrease in free time, authenticity and uniqueness of tourism sites, tourism product and authenticity of tourist experience prevail as the main keywords (Rickly-Boyd, 2012) even though in a pool of internationalisation of the global society practicing a globalized tourism.

The main directions of tourism development tend towards sustainability by reducing the environmental impact of tourist activities which are influenced by the type and quality of services included in a holiday package (Budeanu, 2005) and also by the environmental performance of tourist facilities (Lee, 2001). On the other hand, tourism providers create products that would best fit the particularities of the postmodern consumer eventually generating a customer-oriented market. Two main factors trigger transformation of tourism and they are migration and work. Migration itself creates a certain form of tourism, large masses of people travelling transnationally on medium and long term. Work, on the other hand implies travelling in a globalized world, the entire group of people on the move (Fursich, 2002) therefore determining a mix of business, travelling and leisure in what is voluntary or forced tourism.

Most of the contemporary forms of tourism clearly reflect the preference of tourists for uniqueness and of the destination place, authenticity of the cultural heritage, gazing at everything that is particularly different from the everyday environment. Therefore, supporting Urry's, debate on tourist gaze, we argue that postmodern tourists all over the world have become fond of the local, of the regional, of that cultural, of that handmade souvenirs, and of that brand that they 
discover, all of them carrying a various level of symbolism and of course their perception being modelled by their cultural background, their home country, social-status or personality.

Even though postmodern tourists hold on to the private travelling, they are no longer insulated but they reach a high level of comfortableness with the host space and people. They want to integrate, they need to participate for their holiday is complete and their need for authenticity and uniqueness is fulfilled.

\section{Prospective tourism types - metaphors or not?}

We also need to consider the shifts from classical to newly emergent types in the tourism economy and go from narrowly debating on the possible future scenarios to widely consider new possible identities that might represent a call for the internationalization, informationalization, commonness and trans-nationalization of the tourism phenomenon. Enhancing the debates on prospective tourism the futurologist Ian Yeoman (2012) challenges the readers with many ifs or what ifs on the future of tourism. Coming up with 17 mega drivers for the evolution of tourism Yeoman makes several creative assumptions providing quite a few mental images on how tourism and travellers of the future will be shaped and the most driving motivations for the continuation of tourism as a phenomenon. Therefore, tourism is a non-static process whose dynamics is strongly connected to the consumers market, to the political and economic global changes and eventually to its own inner dynamics. The way we envision the future of tourism involves the emergence of new face of tourism, in which technology is highly imprinted. In the end, globalization of tourism enhances the mutual interests of disparate working people around the world both hosts and guests (McGuckin, 2005). How- ever, judging on the evolution cycle of tourism, we have to admit that tourism will not end with niche tourism and in the far future we expect to witness a decentralized globalized tourism, a globalized niche tourism which would positively embrace and express a destructured mass tourism. Much more, it could also take other shapes in the future, here proposing for admission the notions of nootourism and non-tourism, the tourism of post-tourists.

\section{Emergence of nootourism. Post-tourism and post-tourists}

Debates of the shape of tourism in the future have already started and several scenarios for the 2030 and 2050 strongly correlate it with science and technology development (Yeoman, 2012) the type of sustainable economy after overcoming the economic and energetic crises, along with the demographic evolution. The new dominant tourism form resulted after all these transformations of the human civilization shall be based on knowledge and informational technology. Therefore, we propose to name it the age of nootourism, a new entry in both time and global economy. All types of tourism in this age shall be based on knowledge, science and technological revolution at all levels, minimizing the significance of social class and increasing tourism consumption, as lifestyle. This feature will be the main attribute of the knowledge-based society. Universities, research institutes all over the world will generate increasingly large human flows for learning, studying, research, conferences or internships at regional and global levels. This flow will be the carrier of need as well: need of rest, relaxation or leisure, and subsequently the generator of tourism flows, at the same time tourists integrating themselves in the respective local environment living the tourist experience as one of the locals. The current classical forms of tourism will eventually retreat and 
even go exempt. Those who will not disappear will transform into tourism niches and will always remain attractive and interesting (i.e. balneary tourism, safari, extreme, sex, ecological and others), many of them having their roots in the ancient times.

Knowledge-based tourism and informational technology shall focus on the possibilities provided by the future informational technology. Besides transferring most of tourism informational services on digital platforms for accessing the information from all sorts of terminals such as mobile phones or other types of gadgets, other technologies will develop in order to facilitate exploration, knowledge, relaxation and emotional feeling such as: i) participatory exploration through VR avatar technology; ii) exploration of museums or any kind of tourist attractions through virtual platforms; iii) direct exploration of urban centres by using CAT technology for instantaneous translation; iv) robotized assistance in travelling; v) using 3D holographic images in virtual exploration of tourist attractions and communication with other persons; vi) using artificial intelligence in tourist assistance and guided tours; vii) generating artificial virtual environments (3D, 4D and 5D) and exploring a wide range of sensorial and extra-sensorial reality through HAPTIC technology.

Therefore, even though tourism is all about experiences and not about virtual worlds (Yeoman, 2012) we should acknowledge the inherent digital world development and its interference into the practical and material tourism practice environment especially designed for the farther correlated armchair travellers described by Moss (1998) cited by Fursich (2002). A special form of tourism that will certainly develop will be the space and cosmic tourism supported by certain spaceships and orbital stations developed with this purpose. This new age of nootourism shall be the last phase of tourism development after which non-tourism will take its place in a new century.

\section{Non-tourism}

The age of non-tourism shall develop after the globalisation in the age of planetary civilization. The main feature of this age shall be the change of the existential paradigm and definitive transfer towards a resourcebased and highly technological economy. The everyday existence of the individual and society shall not be affected by any material lacks and lifestyle shall be integrated and oriented towards knowledge and travelling. The daily work routine shall disappear and subsequently exhaustion and tiredness shall be considerably reduced. Thus, tourism shall not exist as an economic activity anymore, but as an integrated part of the daily life of the individual, animated by knowledge and relaxation. Tourism will be perceived as an imbrication in the everyday rather than as a special, separate field of activity and enquiry (Edensor, 2001). This might be the last era for the tourism development, that can be foreseen at least for the far future of the humankind, after which, who knows what it will be?!

\section{Conclusion}

We are living in full postmodernist times and we assist to the most ample social and economic convulsions. The current economic paradigm that we still follow is the market economy, whose main aim is growth. However, we most often forget that we live in a finite world in terms of space and resources. And the answer to the question where are we going to is nowhere. The most sombre scenario the entire civilization is getting towards extinction based on its own principles and decisions. Economic growth cannot exist infinitely in a finite world as ours. Something is wrong in our way of being. That something is indeed the economic paradigm that we fight to apply and stoically maintain even with the price of the future. 
It is time for great changes and decisions in order that our generation should not remain in the history of the humankind as being the one that endangered the future for temporary wellbeing. That future however implies a radical change of the current economic paradigm generically called the age of capitalism, and turn to a new age, that of human and environmentally friendly - a resourcebased economic paradigm. This would be the only one way of the future and for this there are important decisions to be taken.

As a socioeconomic activity, tourism is also affected by changes and transitions. We even assist to a radical transformation of tourism in the postmodern times we live. From mass tourism it goes through an ample process of demassification and restructuration into diverse niches. Primarily developed as a means of escaping the everyday life, tourism now reaches new levels of development and practice. Consumers are no longer especially chosen due to their (high) social status, but according to their will to travel, or due to several basic causative factors, such as migration or work. Deductively analysed, tourism shows its nature of evolutive phenomenon proving the global transfer from Veblen's conspicuous tourism consumption to the intrinsic one. Location, relocation, distance, time or motivation seem no longer be the main determinants for the practice of tourism as the common causative factors for determining tourism are rather downgraded and replaced by need, openness and thirst for knowledge and discovery. The present future of tourism is niche tourism, which is the response to all ample transformations the society and economy themselves are going through. This form of tourism is very dynamic, adaptable to the transformations the demand goes through and has an impressive capacity to exploit and manage tourism resources at micro-scale. Elements of attraction that would not present any interest for tourism practice until not too long ago, are currently highly debated and have changed the face of world tourism. Given this new coordinate tourism has revigorated recreational activities and become in some cases an existential alternative. Also, tourism has become more environmentally friendly and at the same time a form of preservation in case of various types of habitats, cultures, infrastructures, architecture and even human communities. And if this is the direction of the emergent tourism development then it is not the case to operate other useless experiments, either political or economic but to create the proper framework for this direction of development. Thus, the main trait of postmodern tourism would be represented by demassification and the emergence of niches.

If it were to debate on the farther future of tourism, this would radically transform up to complete imbrication in the daily existence of the individual and of society. Therefore we would not be able to consider tourism a distinctive economic activity, aiming for rest, recreation, leisure or knowledge since in a society of the future as it is seen by futurologists and implicitly by us, all tourism motivational elements will disappear. Society of the future will for sure be a knowledgebased society highly supported by technology and robotics. The last two features will almost entirely supply for the daily routine of a boring and exhausting job that usually hold the most part of the time of a human being and subsequently triggers the need for rest and recreation. Hence, civilization of the future will dedicate itself into overlapping completely the current age, which is marked by gaps (shortages), conflicts and nature degradation by knowledge and technology and will in the end become the first global civilization indeed civilized. At that moment we will no longer speak about tourism since the human existence will be one of permanent knowledge, of travelling and tight relationship with nature of which part we are. However, until that moment foreseen to be after the year 2100 , tourism has to 
go through a distinct age, which we would name the age of nootourism. This age would correspond to the global new enlightenment in which tourism will profoundly blend with technology and will offer feelings and ways of spending free time that today we cannot think of. In conclusion since we are living in the period of great changes that will lead to a new civilization or to nowhere, besides the well-established types of tourism, including niche tourism that has gradually become the pattern of postmodern tourism, we try to propose to acceptance new possible meaningful types of tourism that go beyond postmodern tourism, even to transpose tourism into something other than tourism, such as non-tourism.

\section{References}

Ali-Knight, J. M. (2011), The Role of Niche Tourism Products in Destination Development, PhD Thesis. Available online at: http:// researchrepository.napier.ac.uk/5376/1/ Full_thesis.pdf. Arnould Eric J., Thomson Craig J. (2005) Consumer Culture theory (CCT): Twenty Years of Research, Journal of Consumer research, vol. 31 .

Budeanu, Adriana (2005), Impacts and responsibilities for sustainable tourism: a tour operator's perspective, Journal of Cleaner Production 13 (2005): 89-97.

Daugstad, K., Kirchengast, C. (2013), Authenticity and the Pseudo-Backstage of AgriTourism, Journal of Tourism Research, vol. 43, pp. 170-191.

Edensor, T. (2001), Performing tourism, staging tourism, (Re)producing tourist space and practice, Tourist Studies, vol 1(1) 59-81.

Eugenio-Martina, J. L., Campos-Soria, J. A. (2014), Economic crisis and tourism expenditure cutback decision, Annals of Tourism Research 44 (2014) 53-73.

Fife, Wayne (2004), Penetrating Types: Conflating Modernist and Postmodernist Tourism on the Great Northern Peninsula of New- foundland, Journal of American Folklore 117(464): 147-67.

Franklin, A., Crang, M. (2001), The trouble with tourism and travel theory?, Tourist Studies, vol. 1(1) 5-22.

Fursich, E. (2002), Packaging culture: The potential and limitations of travel programs on global television, Communication Quarterly; Spring 2002; vol 50, no. 2, pp. 204-226.

Hall, C. M. (2011), Health and medical tourism: a kill or cure for global public health?, In Tourism Review, Vol. 66: 1/2, pp.4 - 15 http://www.emeraldinsight.com/journals. htm/ journals.htm?issn=1660-5373\&volu me $=66 \&$ issue $=1 \&$ articleid $=1926820 \&$ sho $\mathrm{w}=\mathrm{html}$

Hannam, K., Butler, G., Morris, P. C. (2014), Developments and key issues in tourism mobilities, Annals of Tourism Research 44 (2014) 171-185.

Jameson, F. (1983), Postmodernism and Consumer Society. Available online at: http:// www9.georgetown.edu/faculty/irvinem/ theory/JamesonPoMo_and_Consumer_ Society.pdf

Lee, K. F. (2001), Sustainable tourism destinations: the importance of cleaner production, Journal of Cleaner Production, 2001; 9(4):313-23.

Mak, H. N. Athena, Lumbers Margaret, Eves Anita (2012), Globalisation and Food Consumption in Tourism, Annals of Tourism Research, vol. 39, 171-196.

Manolache Viorella, Serban Henrieta Anisoara (2012), The Cultural Tourist and the Decoding of the Urban Space: the Coincidence Vocable-Image, Journal of Tourism Challenges and Trends, vol. 5, no. 2, pp. 35-52.

McGuckin, E. (2005), Travelling Paradigms: Marxism, Poststructuralism and the Uses of Theory, Anthropologica; 2005; 47, pp. 67-79.

Novelli Marina (2005), Niche Tourism. Contemporary Issues, Trends and Cases, Elsevier.

Pritchard Annette, Ateljevic Irena (2011), Hopeful Tourism. A New Transformative 
Perspective, Annals of Tourism Research, vol. 38, 941-963.

Richards, G. (2011), Creativity and Tourism. The State of the Art, Annals of Tourism Research, vol. 38, pp. 1225-1253.

Rickly-Boyd, J. M. (2012), Authenticity \& Aura. A Benjaminian Approach to Tourism, Annals of Tourism Research, Vol. 39, No. 1, pp. 269-289.

Tiwsakul Rungpaka Amy, Hackley C. (2012), Postmodern paradoxes in Thai-Asian consumer identity, Journal of Business Research, 65, pp. 490-496.

Tzortzaki, M. Alexia, Mihiotis Athanassios, Agiomirgianakis M. George (2011), The Quest for a New Multidisciplinary Tourism Model, Annals of Tourism Research, vol. 38, 325-330.

Urry, J. (1995), Consuming Places, Routledge, London, UK.

Valtonen Anu, Veijola Soile (2011), Sleep in Tourism, Annals of Tourism Research, vol. 38, no. 1, 175-192.
Van Raaij, W. F. (1993), Postmodern Consumption: Architecture, Art, and Consumer Behaviour, in E - European Advances in Consumer Research Volume 1, eds. W. Fred Van Raaij and Gary J. Bamossy, Provo, UT: Association for Consumer Research, Pages: 550-558. http://www.acrwebsite. org/search/view-conference-proceedings. aspx? $\mathrm{Id}=11634$

Wight, A. Craig (2006), Philosophical and methodological praxes in dark tourism: Controversy, contention and the evolving paradigm, Journal of Vacation Marketing; Apr 2006; 12, 2; pp. 119-129.

Yeoman, Y. (2012), 2050: Tomorrow's Tourist. Scenarios and Trends, Advances in Tourism Series, ed. Stephen J. Page, University of Stirling, UK.

Yuksel E., Sirakaya-Turk E., Preciado S. (2013), Symbolic consumption of tourism destination brands, Journal of Business Research, vol. 66, pp. 711-718. 
